\author{
José Javier Ávila-Cabrera* \\ Universidad Complutense de Madrid, Spain \\ josejaav@ucm.es
}

\title{
IMPROVING ORAL PRODUCTION SKILLS IN THE BUSINESS ENGLISH CLASS THROUGH CREATIVE DUBBING
}

\section{Abstract}

This study focuses on an innovative teaching project entitled Doblaje creativo (Creative Dubbing), which was conducted at the Universidad Complutense de Madrid during the 2019-2020 academic year. Its main goal was to explore the use of creative dubbing as an innovative tool for improving oral production skills in the business English classroom, as well as for other language skills. To this end, twenty students from the Degree in Commerce practised their speaking skills (a measured and dependent variable) in business English through creative dubbing activities (a manipulated and independent variable) - a recent application of didactic audiovisual translation (AVT). Several lecturers from public universities took part in this project, which employed a mixed methods study involving an experimental group $(\mathrm{N}=20)$ and a control group $(\mathrm{N}=20)$. Both quantitative and qualitative data were gathered. The former involved student tasks designed to assess three videorecorded presentations carried out by both groups, serving as pre- and postlanguage tests. The latter involved questionnaires filled in by the students. The results obtained indicate that creative dubbing is indeed a tool that can enhance students' oral skills, motivating them regarding the use of a non-traditional educational methodology, which can be applied in any other English for specific purposes (ESP) context.

\section{Key words}

creative dubbing, business English, English for specific purposes (ESP), oral production, mixed methods.

\footnotetext{
* Corresponding address: José Javier Ávila-Cabrera, Universidad Complutense de Madrid, Facultad de Comercio y Turismo, Av. de Filipinas, 3, 28003 Madrid, España.
} 


\section{INTRODUCTION}

Nowadays, international communication requires university students to improve their English language skills, especially their spoken English, which is one of the most challenging and important skills for them to master. Thanks to globalisation, English is currently considered a lingua franca, so that using it to communicate is of paramount importance.

Therefore, as methods of teaching and learning are constantly changing, teachers and lecturers must learn to use them for the benefit of students of any foreign language. An increasing number of lecturers, teachers and researchers have turned to audiovisual translation (AVT) modes and methodologies for foreign language learning (FLL) because of the many benefits they provide to foreign language professionals and learners. Over the past few decades, the potential of these methodologies has been proven and shared by numerous scholars (ÁvilaCabrera \& Corral Esteban, 2021; Díaz Cintas, 2012; Fernández-Costales, 2017; Sokoli, Zabalbeascoa, \& Fountana, 2011; Talaván, 2013; Vanderplank, 1998).

This paper therefore aims to present the results of an innovative teaching project designed to improve oral production skills in the English for specific purposes (ESP) classroom, more specifically in business English. In addition, it introduces a methodological approach that can be used by other professionals within the scope of ESP. The paper is structured as follows: creative dubbing as one of the most recent applications of didactic AVT is described in the literature review section. Next, a methodological proposal is presented as a possible tool for facilitating the use of AVT in the ESP classroom. The methodological procedures are then addressed, followed by a discussion of the relevant findings. The final section contains some concluding remarks.

\section{LITERATURE REVIEW}

As shown in recent publications by key AVT scholars (Bogucki \& Deckert, 2020, for instance), rapid strides are being made in AVT practices and research. Not only are there emerging AVT modes that offer lecturers and scholars tools for the foreign language classroom - such as the use of video, film and audiovisual media (Herrero \& Vanderschelden, 2019) - but research on AVT is also developing theoretical approaches that combine studies on technology and FLL.

The dubbing of videos is not a new tool in the foreign language classroom. Burston (2005) highlights the benefits of including video dubbing projects as part of the foreign language curriculum to improve language skills (listening, reading, writing, and speaking) as well as technical skills, which can be carried out in the classroom or computer lab. Danan (2010) describes a number of dubbing projects in which students translate short American films from their own language into a foreign language. Such projects aim to enhance aspects such as vocabulary 
acquisition, paralinguistic elements, and register awareness, amongst others. The use of videos by teachers and lecturers is currently a very common part of the multimedia content employed when teaching in the FLL and ESP fields.

It is also worth mentioning the field of mobile-assisted language learning (MALL), which has provided foreign language learners with educational apps. For instance, Zhang (2016) presents English Fun Dubbing, an app for the improvement of oral production skills. The participants in this study, students of Medicine in China, emphasised its user-friendliness, versatility, and authentic language context. Ibáñez Moreno and Vermeulen (2015) introduce the app named VIdeos for SPeaking (VISP), based on audio description, which aims to enhance idiomaticity (in terms of lexicon, phraseological competence, and syntax) in oral production. We can conclude from these examples, and from others (Bolaños-García-Escribano \& DíazCintas, 2019), that dubbing and revoicing with an educational purpose have become a reality both in and outside the classroom.

The field of dubbing should not be mentioned without emphasising the ground-breaking research contributed by Chaume (2020). This author has examined this AVT mode from a theoretical as well as a professional perspective, establishing links between film studies and translation studies (Chaume, 2004). Cerezo Merchán et al. (2016) also conducted an empirical and descriptive study on the professional norms of translation for dubbing on Spanish television. Their work also examines many of the specific problems inherent in this type of translation.

We need to draw a distinction between the didactic tool used in this paper, namely creative dubbing, and some others. Chaume's (2018) reference to amateur dubbing, known as fandubs, and fundubs, is related to the gag dubbing used in TV series, film trailers and cartoons. These are recorded by fans, and the main function of this 'creative translation' is parody. Baños (2019) also explores fandubbing and describes the origins of fandubs and the motivations of those involved in the process of translation. The study also presents examples borrowed from various contexts and at various times in order to shed light on this phenomenon. A study dealing with creative dubbing and subtitling activities called Creative Dubbing and Subtitling: New Resources for Language Learning (CREATE) was also conducted by Talaván (2019). In this study, the author explores the improvement of diverse foreign language skills among the participants, following the production of fake dubbing exchanges and subtitles through the manipulation of original dialogue exchanges for humorous effect. The present paper is influenced by the CREATE project, but in this case, creative dubbing is used for the development of a totally new dialogue for the video itself in an attempt to improve the participants' language skills in the business English classroom. It is also worth noting here that this approach to creative dubbing differs slightly from Chaume's (2018) concept of 'creative translation' since the former excludes the humoristic component.

There are some recent studies within the scope of didactic AVT (Talaván, 2020 ) that cover a combination of dubbing and subtitling to assess the enhancement of speaking and writing in a foreign language, for example those by Talaván and 
Ávila-Cabrera (2015), and Lertola and Mariotti (2017). Intralingual dubbing is explored by Talaván and Costal (2017) in order to assess the validity of this tool for educational purposes in an FLL context. Incalcaterra McLoughlin, Lertola, and Talaván (2020) edited a volume on didactic AVT, which deals with different pedagogical studies and proposals. Another contribution worthy of mention is the Audiovisual Translation as a Tool for the Development of the Multilingual Competence in the Classroom (PluriTAV) research project conducted by the research group CiTrans in collaboration with others such as TRAMA, CenTraS, and CRTTS. The project's main goals revolve round the improvement of foreign languages and the development of multilingual competencies through AVT when used as an educational tool (Martínez Sierra, 2021). A number of didactic sequences (including dubbing, subtitling, free commentary, and audiodescription) can be downloaded from the project's web platform. ${ }^{1}$

This paper not only focuses on a single innovative teaching project, but also aims to enrich our knowledge and understanding of literature related to didactic AVT with a methodology that can be implemented within the scope of ESP.

\section{THE PROJECT}

This paper deals with an innovative teaching project entitled Doblaje creativo (Creative Dubbing), which was conducted at the Universidad Complutense de Madrid, during the first semester of the 2019-2020 academic year. Various lecturers from public universities in Madrid participated in the project including six from the Universidad Complutense de Madrid, three from the Universidad Nacional de Educación a Distancia (UNED), and one from the Universidad Autónoma de Madrid. A detailed description of the project is presented in the following sections.

\subsection{Goals and participants}

This study evaluates the extent to which students' oral production skills can be improved through creative dubbing, an AVT mode in which participants actively dub videos creatively. Students provide the dialogue exchanges between the speakers and the narrator of the video clip in a way that enables them to match both the dialogue and the images shown through the visual channel. The goal of the study concerns the improvement of oral skills needed in business English through the creation of dialogue and its narration accompanying a video clip. The dialogue exchanges produced by the students (in the context of commerce and/or business) may also improve other skills, namely written production and vocabulary acquisition, which will then be transferred to oral English creatively.

${ }^{1}$ http://citrans.uv.es/pluritav/sd/?lang=es 
Twenty-five students participated in the study, making up the experimental group (EG). These students were enrolled in a business English course, which was part of the second year of the Degree in Commerce at the Universidad Complutense de Madrid. Additional twenty-five students from the same classroom who did not participate in the project but had submitted compulsory video-recorded presentations were randomly chosen as the control group (CG). As a reward for participating in and completing all the necessary tasks, one point (out of a maximum of ten) was added to the EG students' final mark. One drawback with regard to the number of participants should also be mentioned here. Namely, out of the twentyfive students who originally signed up for the project, only twenty completed all the tasks. The EG was therefore analysed on the basis of a smaller sample of twenty students.

\subsection{Research questions}

The research employed a mixed methods approach (Robson \& McCartan, 2016) as both quantitative and qualitative information was gathered, thus triangulating the data in an attempt to observe the phenomenon under study from different perspectives.

The study provides answers to three research questions, one primary and two secondary. The primary question was as follows:

1. Can creative dubbing be used as a valid tool for the improvement of oral production skills in English?

The quantitative data obtained from the video-recording and creative dubbing tasks submitted by the students, along with the qualitative data gathered from their responses in the questionnaires, were used to answer this primary research question.

The secondary research questions were as follows:

2. Did the students feel that they had improved any other skills through creative dubbing?

In order to address this question, the students' responses to the post-questionnaire were analysed and discussed in light of the quantitative results. However, these responses were exclusively based on the students' own perceptions of their achievements and the enhancement of other language skills.

3. Was the project well-received by the participants? 
The students' own perceptions following their participation in the project were considered in order to address the last question. Their marks were analysed and then discussed in the light of their perceptions concerning the value of the project.

\subsection{Procedures}

Information concerning the project was initially given to the participants in their business English class. The purpose behind this innovative teaching project was explained to them, as was the fact that for their participation they would be awarded an additional point towards their final mark (ranging between 0 and 10). Table 1 shows all the tasks to be completed during the project.

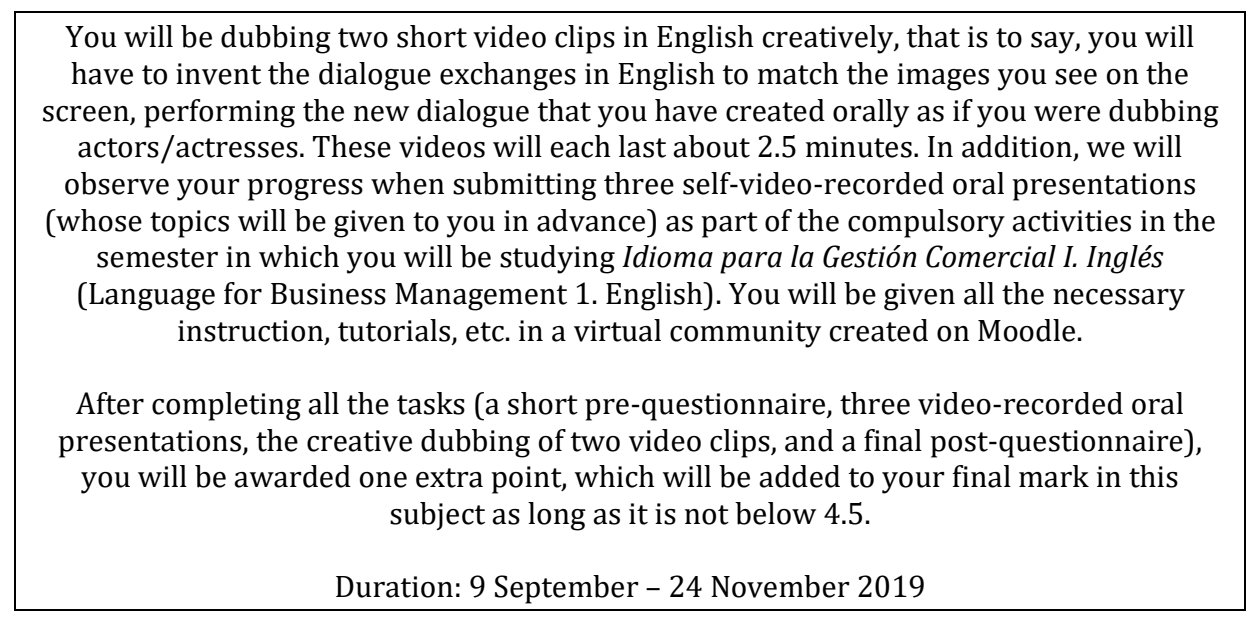

Table 1. The project outline

The participants were informed that, as they would need to spend extra time on the assigned tasks, they should consider carefully whether they were willing to participate in the project or not. Since many of the students had not already been familiar with AVT, a lecture was devoted to explaining it (Talaván, Ávila-Cabrera, \& Costal, 2016), with special attention given to dubbing. The students were then informed that "dubbing consists of translating and lip-syncing the script of an audiovisual text, which is then performed by actors directed by a dubbing director" (Chaume, 2013: 107). In the case of creative dubbing, we are dealing with a type of revoicing where there is a change to the original voice of the speaker(s) and narrator, but in an inventive way. Thus, it is the student who invents a new script to fit in with the information shown via the audio channel (in the form of the speakers' and narrator's tone and pitch, which can also be modulated), and the visual channel (paying particular attention to what happens on the screen).

The participants had to carry out the following tasks: (1) the EG was asked to fill out a pre-questionnaire, whose objective was to gather general information 
about their English language proficiency, age, mother tongue, etc.; (2) both the EG and the CG had to submit three video-recorded presentations related to business English (Appendices A, B and C). They also performed additional tasks during lab classes such as grammar and vocabulary tests, listening comprehension activities, and written production exercises; (3) the EG had to carry out two creative dubbing tasks (Appendices D and E), with two film trailers to be dubbed in English creatively; the films were: Once Upon a Time in Hollywood (directed by Quentin Tarantino in 2019), and The Wolf of Wall Street (directed by Martin Scorsese in 2013). During the task, students were instructed to make use of certain terms/phrases taught in their business English course (B1+ level according to the CEFR). The choice of these two trailers was made because the scenes shown allowed students to use these terms/phrases in their creative dialogue exchanges. The creative dubbing tasks were then submitted by the EG after handing in the first and the second videorecorded presentations; (4) the EG had to fill out a post-questionnaire (Appendix F) in which the participants were supposed to answer questions related to the project itself.

A virtual space on Moodle was created giving all the participants easy access to the different tasks and deadlines. Table 2 shows the tasks that were shared by the EG and CG, as well as those that were exclusively carried out by the EG.

\begin{tabular}{|l|l|}
\hline 2019-2020 course & Tasks \\
\hline 9-15 September & Sign up for pre-questionnaire (EG) \\
\hline 16- 23 September & Video-recording of oral presentation 1 (done in class) (EG \& CG) \\
\hline 30 September -13 October & Creative dubbing 1 (done at home) (EG) \\
\hline 14- 21 October & Video-recording of oral presentation 2 (done in class) (EG \& CG) \\
\hline 28 October -10 November & Creative dubbing 2 (done at home) (EG) \\
\hline 11- 18 November & Video-recording of oral presentation 3 (done in class) (EG \& CG) \\
\hline 25 November - 8 December & Post-questionnaire (EG) \\
\hline
\end{tabular}

Table 2. The project timeline and tasks

The software program recommended by the project's researchers as suitable for dubbing the videos was Wondershare Filmora9 (https://filmora.wondershare.com), given that it was free and considered to be user-friendly. A tutorial was uploaded to the virtual space to help any students who were not familiar with this video editor, and a forum for general questions was also created to assist with any technical issues. The students were given the opportunity to use a device of their choice for the recording of the oral presentation video, which included, among other things, a smartphone or video-recording software program. All the tasks were uploaded by the participants of the EG and CG to the virtual platform for evaluation. 


\subsection{Rubrics}

The video-recorded presentations were compulsory activities of the course and as such were assessed by the students' lecturer using a rubric adapted from Cambridge Speaking performance B2² and the CREATE project (Talaván, 2019) (Table 3).

\begin{tabular}{|l|l|l|l|l|l|}
\hline \multicolumn{1}{|c|}{$\begin{array}{l}\text { Poor } \\
(0-0.9 \\
\text { points) }\end{array}$} & $\begin{array}{l}\text { Satisfactory } \\
(1-1.4 \\
\text { points) }\end{array}$ & $\begin{array}{l}\text { Good } \\
(1.5-1.9 \\
\text { points) }\end{array}$ & $\begin{array}{l}\text { Excellent } \\
\text { (2 points) }\end{array}$ & Mark \\
\hline $\begin{array}{l}\text { Pronunciation and Intonation } \\
\text { (word stress and sounds } \\
\text { articulated clearly) }\end{array}$ & & & & \\
\hline $\begin{array}{l}\text { Grammar (the student uses a } \\
\text { range of grammatical forms } \\
\text { correctly) }\end{array}$ & & & & & \\
\hline $\begin{array}{l}\text { Vocabulary (the student uses } \\
\text { appropriate vocabulary) }\end{array}$ & & & & \\
\hline $\begin{array}{l}\text { Fluency (the student produces } \\
\text { extended stretches of } \\
\text { language fluently) }\end{array}$ & & & & & \\
\hline $\begin{array}{l}\text { Content (the student } \\
\text { addresses the items outlined } \\
\text { in the task) }\end{array}$ & & & & & \\
\hline Grand total & & & & \\
\hline
\end{tabular}

Table 3. Video-recorded presentation rubric

We used an adapted version of the rubric shown in Table 3 for the creative dubbing assessment submitted by the EG and assessed by all the researchers involved in the project (Table 4).

\begin{tabular}{|l|l|l|l|l|l|}
\hline & $\begin{array}{l}\text { Poor } \\
(0-0.9 \\
\text { points })\end{array}$ & $\begin{array}{l}\text { Satisfactory } \\
(1-1.4 \\
\text { points) }\end{array}$ & $\begin{array}{l}\text { Good } \\
(1.5-1.9 \\
\text { points) }\end{array}$ & $\begin{array}{l}\text { Excellent } \\
\text { (2 points) }\end{array}$ & Mark \\
\hline $\begin{array}{l}\text { Pronunciation and Intonation } \\
\text { (word stress and sounds } \\
\text { articulated clearly) }\end{array}$ & & & & & \\
\hline $\begin{array}{l}\text { Grammar and Vocabulary (the } \\
\text { student uses a range of } \\
\text { grammatical forms and } \\
\text { appropriate vocabulary) }\end{array}$ & & & & & \\
\hline
\end{tabular}

2 https://www.cambridgeenglish.org/images/168619-assessing-speaking-performance-at-level-b2.pdf 


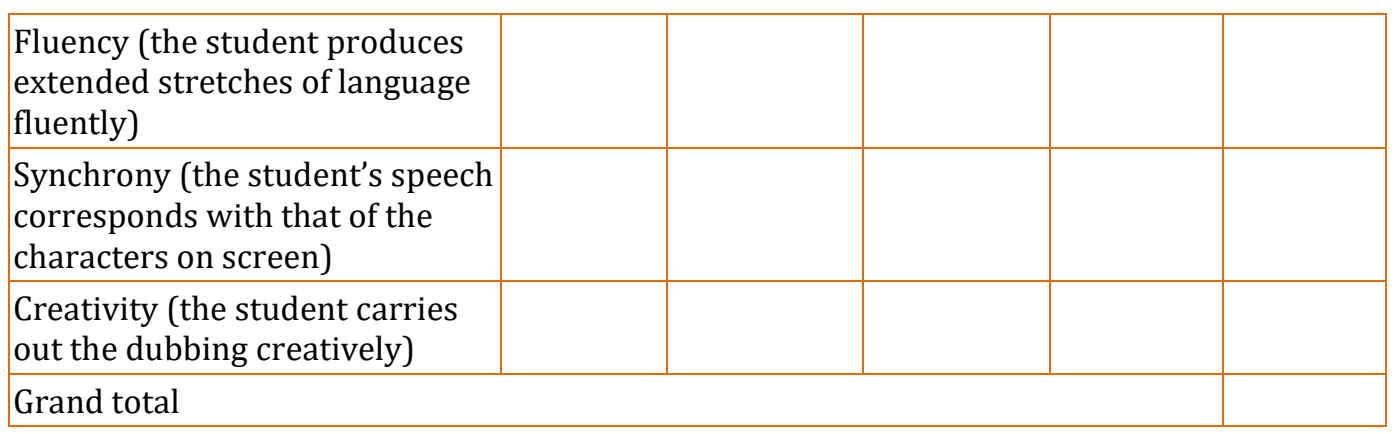

Table 4. Creative dubbing rubric

Because the task of creative dubbing entailed the evaluation of a number of additional features, namely those related to synchrony and creativity, the rubric presented in Table 4 differs from that used in Table 3.

\section{DATA ANALYSIS}

This section first details the tasks performed by both groups (video recording and creative dubbing), and then provides a statistical description of the results.

\subsection{Qualitative data: Pre-questionnaire}

An initial questionnaire was completed by the EG students before participating in the project. There was originally room for twenty-five participants, a number attained within the first few days after publishing the announcement. Eighty percent of the students were between eighteen and twenty-one years of age, and the remaining between twenty-two and twenty-five. The participants' mother tongues were Spanish (52\%), Chinese (44\%), and Arabic (4\%), with the majority being female $(60 \%)$. The first questions involved the respondents' personal perception of their levels of English proficiency in accordance with the Common European Framework of Reference for Languages (CEFR) (Council of Europe, 2001) descriptors. In terms of their English oral skills, 8\% professed to be at an A1 level, 28\% said that their level was A2, 32\% that it was B1, and 32\% said that it was $\mathrm{B} 2$. This question was necessary as the students did not have to submit a proficiency certificate in English to enrol in their degree course.

Some of the students gave the following answers to the open-ended questions as reasons for participating in the project: "I need extra practice to improve my English speaking skills", "I want to learn how to dub videos", and "I want to get the extra mark."

The questionnaire also contained questions relating to the students' consumption of audiovisual content with English subtitles. The responses were 
balanced: none indicated that they had never used them, 24\% answered hardly ever and $32 \%$ answered sometimes. These responses accounted for a majority of $56 \%$. By contrast, out of the remaining 44\%, 16\% indicated often, $24 \%$ most of the time and $4 \%$ always. As these results corresponded to the students' consumption of audiovisual content, we are not able to state categorically that their familiarity with this type of content in English represented an influential factor in the results discussed further on.

Ascertaining whether some of the students had previously actively used dubbing (when they, as users, dub videos themselves) was interesting, and when they were asked about their previous dubbing experience with some software programs (Windows Movie Maker, iMovie, LipDub...), 64\% indicated they had never dubbed anything and only 32\% had dubbed a few clips. However, none had participated in a project where creative dubbing was carried out as a language learning task.

\subsection{Quantitative data}

As already stated, both the EG and CG had twenty participants each. Both groups were selected at random, and there was no difference in their level of spoken English before starting the project. This is reflected in the following statistical data obtained by the $t$-test, with the results of the first oral presentation being analysed and compared in both groups.

\begin{tabular}{|l|l|l|}
\hline & $\begin{array}{l}\text { Video-recorded } \\
\text { presentation 1 } \\
\text { in the CG }\end{array}$ & $\begin{array}{l}\text { Video-recorded } \\
\text { presentation 1 } \\
\text { in the EG }\end{array}$ \\
\hline Mean & 6.72 & 6.12 \\
\hline SD & 1.776 & 1.818 \\
\hline SEM & 0.397 & 0.406 \\
\hline Confidence interval & $95 \%$ : from -0.615 to 1.815 \\
\hline$p$-value (2-tailed) & 0.314 & \\
\hline$t$-value & 1.033 & \\
\hline
\end{tabular}

Table 5. Results of the comparison of the mean values of the first video-recorded presentation in both groups using an unpaired sample $t$-test

As shown in Table 5, the comparison of the results for the first video-recorded presentation shows that the starting level was similar in both groups, as is shown by the mean difference (0.60). Likewise, the $t$-value is relatively low, and $p$ is higher than the significance level, which shows that there is no significant difference between the two sample sets. It also shows that the level of the CG students was slightly higher than that of the EG students, as reflected by the mean values (6.72 vs. 6.12). 
The results obtained by the EG in the two creative dubbing tasks show the impact of completing the special audiovisual task on the students' performance in terms of their video-recorded tasks. The results (assessed between 0 and 10) are shown in Figure 1. It is important to clarify here that the marks obtained in Figure 1 are for the purposes of information only, as they correspond to the students' progress in the tasks performed, which did not constitute the goal of the project itself.

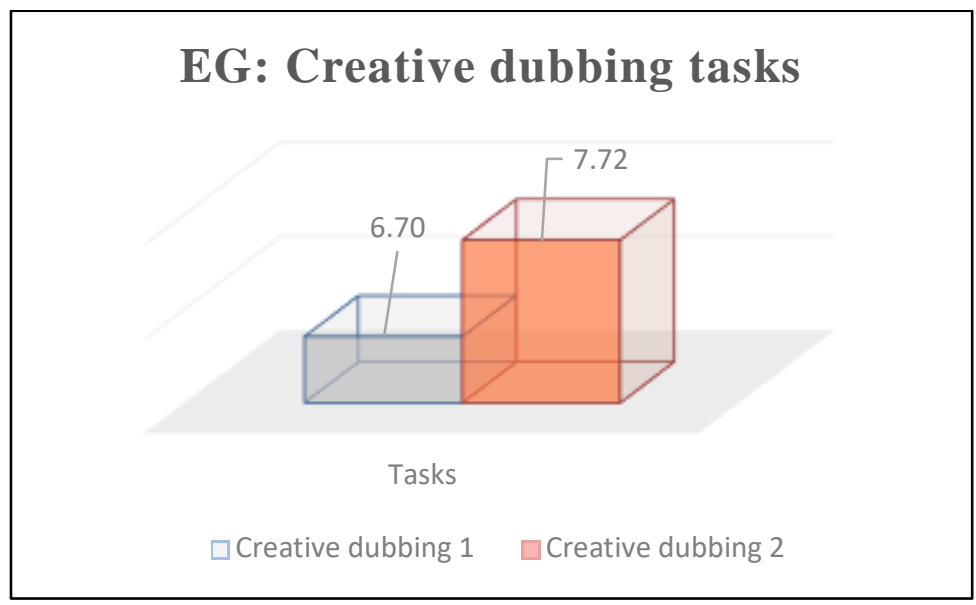

Figure 1. Experimental group: Creative dubbing results

Figure 1 shows that there was an improvement of +1.02 points between the mean values of the first (6.70) and the second (7.72) submission of the creative dubbing tasks carried out by the EG. The median was 7 for the first task and 8 for the second. These data show progressively better results as a whole. The students were given feedback on their first creative dubbing activity so that they could improve their performance in the next. They relied on the information provided in the rubric (Table 4), which relates to pronunciation and intonation, grammar and vocabulary, fluency, synchrony, and creativity. Thus, the creative dubbing tasks, which were used as a means of attaining the goal of the project (the EG participants' oral improvement in English), may have influenced the participants' interest, as is borne out by the quantitative data.

As we have seen, the improvement of the students' oral skills was the main aim of this project. We therefore evaluated the results of the EG's video-recorded presentations and observed their progress, as shown in Figure 2. 


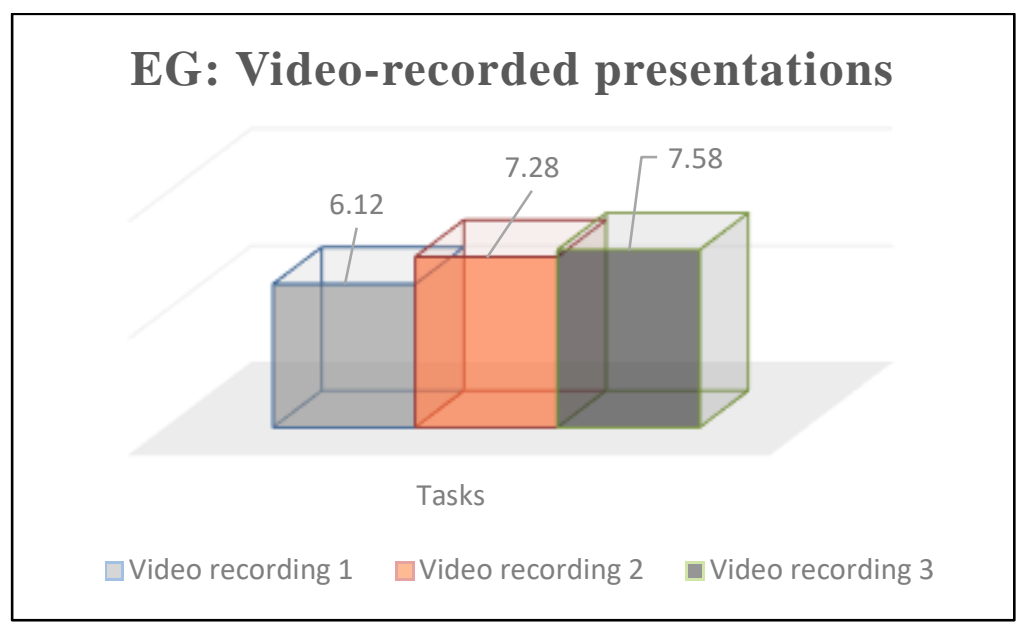

Figure 2. Experimental group: Results of the video-recorded presentations

Based on the data contained in Figure 2, which show the evaluation of videorecorded presentations (assessed between 0 and 10), we can see an improvement in the average mark of +1.16 points between the first (6.12) and the second (7.28) task. Between the second (7.28) and the third (7.58) task, the improvement was +0.30 . And finally, between the first and the third task, there was an improvement of +1.46 . The median in the first task was 6.25 , and in the second and third 7.5 and 7.75 respectively. The quantitative data therefore revealed an evident improvement in the participants' speaking skills.

We also observed the improvement of the CG's oral production skills in business English. The results obtained in the evaluation of the video-recorded presentations (assessed between 0 and 10) can be seen in Figure 3.

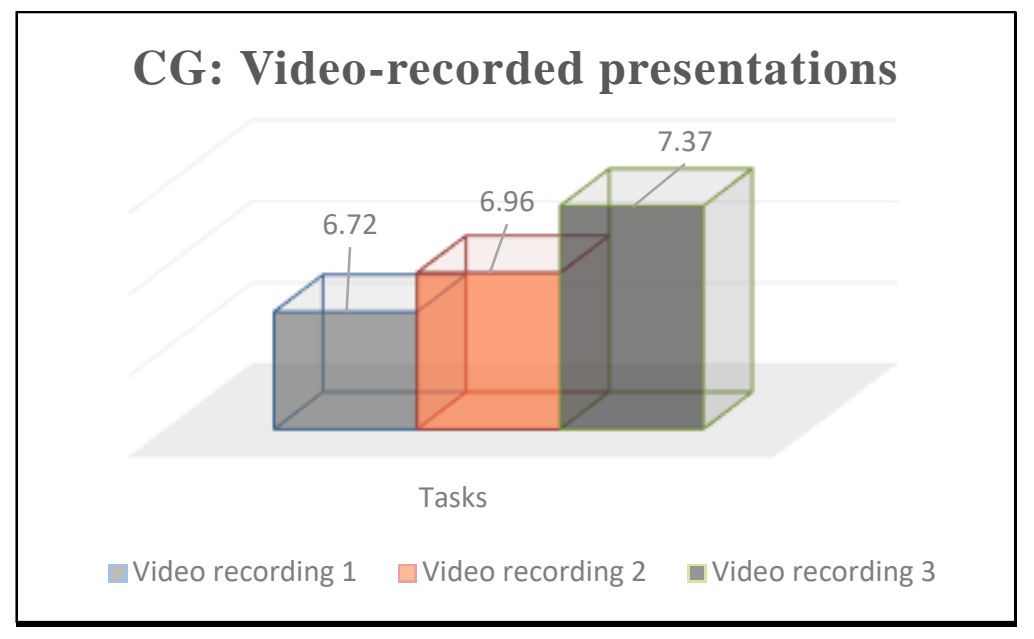

Figure 3. Control group: Results of the video-recorded presentations 
These students improved during the course of the three tasks assigned as part of their class activities. From the first (6.72) to the second (6.96) task, the average mark improved by +0.24 points and from the second (6.96) to the third (7.37) by +0.41 , so that there was an overall improvement in their average marks of +0.65 between the first and the third task. The median between the three tasks was 6.75 , 6.75 and 7.25 respectively. If we compare the data on the video-recorded presentations with the EG's results, we can see that the latter improved by +0.81 points more than the CG from a quantitative point of view.

Now that information on the basic measures of the central statistical tendency - namely the mean and the median for each group of students - has been provided, we will now turn to more complex statistical procedures in order to gain a more insightful understanding of the relationship between the different variables. A paired or dependent sample $t$-test was carried out first of all in order to determine whether the difference between the mean values of the two creative dubbing tasks was significant.

\begin{tabular}{|l|l|l|}
\hline & $\begin{array}{l}\text { Creative dubbing } \\
\text { task 1 }\end{array}$ & $\begin{array}{l}\text { Creative dubbing } \\
\text { task 2 }\end{array}$ \\
\hline Mean & 6.700 & 7.725 \\
\hline SD & 1.681 & 1.428 \\
\hline SEM & 0.376 & 0.319 \\
\hline Confidence interval & $95 \%:$ from -1.342 to -0.708 \\
\hline$p$-value (2-tailed) & 0.0445 & \\
\hline$t$-value & 6.7596 & \\
\hline
\end{tabular}

Table 6. Results of the comparison of the mean values of the two creative dubbing tasks using a paired sample $t$-test

As the $t$-value was relatively high, and $p$ was, at least, slighly lower than the significance level, we should assume that there was a relatively large difference between the two sample sets, and that there was a statistically significant difference between the mean values of the two samples. This is corroborated by the difference between the mean values (1.025), showing that the EG's improved performance in the second task was not coincidental. We could, in fact, attribute this result to the students' improved knowledge of this type of audiovisual activity after carrying out the first creative dubbing task.

Following the $t$-test, the one-way (within subjects) analysis of variance (ANOVA) - an extension of the $t$-test - was used to determine whether there were any statistically significant differences between the mean values of the three videorecorded presentations in each group. We were therefore in a position to deduce whether the difference was significant and if it could be attributed to whether the creative dubbing tasks were carried out effectively or not. 


\begin{tabular}{|l|l|l|l|}
\hline Experimental Group & \multicolumn{3}{|l|}{} \\
\hline & Task 1 & Task 2 & Task 3 \\
\hline Mean & 6.12 & 7.28 & 7.58 \\
\hline SD & 1.81 & 1.75 & 1.85 \\
\hline \multicolumn{4}{|l|}{} \\
\hline$F$-value & 3.64 & & \\
\hline$p$-value & 0.0325 & & \\
\hline
\end{tabular}

Table 7. Results of the comparison of the mean values of the three video-recorded presentations carried out by the EG using ANOVA

\begin{tabular}{|l|l|l|l|}
\hline Control Group & \multicolumn{3}{|l|}{} \\
\hline & Task 1 & Task 2 & Task 3 \\
\hline Mean & 6.72 & 6.96 & 7.37 \\
\hline SD & 1.77 & 1.85 & 1.89 \\
\hline \multicolumn{4}{|l|}{} \\
\hline$F$-value & 0.6383 & & \\
\hline$p$-value & 0.5319 & & \\
\hline
\end{tabular}

Table 8. Results of the comparison of the mean values of the three video-recorded presentations carried out by the CG using ANOVA

As Table 7 shows, the $F$-value (3.64) in the comparative analysis of the mean values in the EG was relatively high, and the $p$-value $(0.0325)$ was considerably lower than the significance level. It may therefore not be possible to accept the null hypothesis of equality between the mean values, and we should consequently assume that there were indeed significant differences between the groups. By contrast, Table 8 shows that the $F$-value $(0.6383)$ for the CG was rather low, and the $p$-value (0.5319) was higher than the significance level, which means that the difference between the mean values for the CG was not statistically significant. In summary, in the EG the null hypothesis is rejected as the differences between the mean values are significant. This difference should not therefore be seen as merely accidental, but the difference between both groups could be explained by the realisation of other tasks, especially with regard to the EG. Finally, the fact that the difference was more noticeable in the EG than in the CG might be explained by the fact that the creative dubbing tasks had a positive influence on the development of the EG students' performance with regard to the video-recorded presentations and might consequently also explain the more significant development between the speaking skills of these students. This relationship is supported by the basic statistical results, as illustrated by the difference in the average marks achieved by both groups in terms of improving their spoken English (an overall improvement of +1.46 points in the EG and +0.65 in the CG). This confirms the fact that the EG improved more than the CG from a quantitative point of view. 
Additionally, post-hoc testing using ANOVA was conducted in order to determine whether or not there was a difference between one or more pairs of groups:

\begin{tabular}{|l|l|l|l|l|l|}
\hline & $\begin{array}{l}\text { Sum of } \\
\text { squares }\end{array}$ & df & Mean square & $\boldsymbol{F}$ & Sig \\
\hline $\begin{array}{l}\text { Between } \\
\text { groups }\end{array}$ & 4.303 & 2 & 2.151 & 0.665 & 0.524 \\
\hline $\begin{array}{l}\text { Within } \\
\text { groups }\end{array}$ & 77.697 & 25 & 3.237 & & \\
\hline Total & 82.000 & 27 & & & \\
\hline
\end{tabular}

Table 9. Results of the comparison of the mean values of the three video-recorded presentations in both groups using an F-statistic (ANOVA result)

As shown in Table 9 above, the value of $F$ is 0.665 , which does not reach a significance level with a $p$-value of 0.524 (less than the 0.05 alpha level). This means that the difference between the mean values of the different presentations is not statistically significant in either group.

Finally, other $t$-tests were carried out in order to determine whether the difference between the mean values of the first two and the last two video-recorded presentations was significant in each group.

\begin{tabular}{|l|l|l|l|l|}
\hline & $\begin{array}{l}\text { EG- } \\
\text { Presentation 1 }\end{array}$ & $\begin{array}{l}\text { EG- } \\
\text { Presentation 2 }\end{array}$ & $\begin{array}{l}\text { EG- } \\
\text { Presentation 2 }\end{array}$ & $\begin{array}{l}\text { EG- } \\
\text { Presentation 3 }\end{array}$ \\
\hline Mean & 6.12 & 7.28 & 7.28 & 7.58 \\
\hline SD & 1.81 & 1.75 & 1.75 & 1.85 \\
\hline SEM & 0.406 & 0.392 & 0.392 & 0.415 \\
\hline Confidence interval & $95 \%$ : from -1.771 to -0.553 & $95 \%$ : from -0.891 to 0.291 \\
\hline$p$-value (2-tailed) & 0.0008 & & 0.3016 & \\
\hline$t$-value & 3.9961 & & 1.0620 & \\
\hline
\end{tabular}

Table 10. Results of the comparison of the mean values of the video-recording tasks in the EG using a paired sample $t$-test

As is shown in Table 10, $t$ was relatively high and $p$ slightly lower than the significance level when the mean values of the first two video-recorded presentations in the EG were compared. This is statistically significant and shows that the students' progress in terms of these two tasks should be linked to the influence of an external factor - most probably carrying out the creative dubbing tasks - rather than being merely coincidental. The fact that the $t$-score and the $p$ value were not significant in the second section could be explained either by the fact that the students improved more between the first two tasks than between the last two $(+1.16$ vs. +0.30$)$, or by the fact that the students were more motivated when they carried out the first creative dubbing task. Another possible explanation is that 
the experimental treatment led only to a slight improvement and that, in order for the students to raise their English to a higher level, additional factors in the treatment need to be taken into account.

\begin{tabular}{|l|l|l|l|l|}
\hline & $\begin{array}{l}\text { CG- } \\
\text { Presentation 1 }\end{array}$ & $\begin{array}{l}\text { CG- } \\
\text { Presentation 2 }\end{array}$ & $\begin{array}{l}\text { CG- } \\
\text { Presentation 2 }\end{array}$ & $\begin{array}{l}\text { CG- } \\
\text { Presentation 3 }\end{array}$ \\
\hline Mean & 6.72 & 6.96 & 6.96 & 7.37 \\
\hline SD & 1.77 & 1.85 & 1.85 & 1.84 \\
\hline SEM & 0.397 & 0.414 & 0.414 & 0.413 \\
\hline Confidence interval & $95 \%$ : from -0.608 to 0.133 & $95 \%$ : from -0.7790 to 0.0540 \\
\hline$p$-value (2-tailed) & 0.1960 & & 00843 & \\
\hline$t$-value & 1.3402 & & 1.8215 & \\
\hline
\end{tabular}

Table 11. Results of the comparison of the mean values of the video-recording tasks in the CG using a paired sample $t$-test

Unlike for the EG, when comparing the mean values in the first section, the $t$ value for the CG was very low and the $p$-value higher than the significance level, which might reflect the absence of an external factor influencing the marks obtained by these students.

In conclusion, the results of statistical testing appear to show a direct correlation between the development of the EG's oral production skills (Figure 2) and the realisation of additional creative dubbing tasks (Figure 1).

\subsection{Qualitative data: Post-questionnaire}

In order to gather the qualitative data (see Appendix F), we adopted a Likert scale based on six levels of measurement in an attempt to inspire the students to make a choice and give more precise results, therefore avoiding a middle point. They are as follows: 1 (completely useless), 2 (mostly useless), 3 (somewhat useless), 4 (somewhat useful), 5 (mostly useful), and 6 (completely useful).

The personal details of the participants were as follows: $56.25 \%$ were Spanish, $37.5 \%$ Chinese and $6.25 \%$ Arab. The female participants accounted for $75 \%$ versus $25 \%$ of their male counterparts, and $56.25 \%$ of them were aged between 18 and 20, while $43.75 \%$ were older than 20 . When they were asked about the time devoted to the video-recording tasks, $75 \%$ indicated that they had spent between one and three hours and $25 \%$ between three and five hours. The students found that the dubbing tasks required the most time, with $62.5 \%$ indicating that they had spent between one and three hours on them, $31.25 \%$ between three and five and $6.25 \%$ more than five hours. These results seem to tally with expectations considering that this was a new task for most of them. Some of the participants said that they had experienced technical difficulties when using the dubbing software, but as the students did not ask technically-related questions regarding the video-recording or creative dubbing 
tasks on the forum or contact the project coordinator, we can assume that they eventually managed to resolve their difficulties.

Further questions (see Appendix F) related to the participants' impressions of the project. These were as follows:

5. How useful do you find these types of activities in terms of enhancing your English language skills?

5.1. Linguistic creativity skills (or the ability to create new dialogue exchanges) The majority (87.6\%) of the responses were positive, with $37.5 \%$ of the students selecting somewhat useful, $31.3 \%$ opting for mostly useful and $18.8 \%$ saying that they were completely useful. By contrast, only $12.4 \%$ found them somewhat useless.

5.2. Listening comprehension

The answers were more varied in this case, although most were positive $(68.9 \%)$, i.e. $18.8 \%$ of the students indicated that the tasks were somewhat useful, $31.3 \%$ mostly useful, and $18.8 \%$ completely useful. Conversely, $6.1 \%$ found them mostly useless and $25 \%$ somewhat useless. This could be explained by the fact that the students did not follow the original audio as they had to create their own dialogue exchanges.

5.3. Writing production skills

In order to create a new dialogue for each of the creative dubbing tasks the participants had to make use of their writing skills. Their responses as to the usefulness of these tasks were as follows: the majority (68.9\%) expressed a positive outcome, with $18.8 \%$ indicating that the activities were somewhat useful, $31.3 \%$ mostly useful and 18.8\% completely useful. By contrast, $6.1 \%$ selected mostly useless and $25 \%$ somewhat useless.

\subsection{Speaking skills}

This question was crucial as improving the students' speaking skills constituted one of the project's main goals. The students' responses were mostly positive $(87.4 \%)$, with $25 \%$ indicating that the tasks were somewhat useful, $25 \%$ opting for mostly useful and 37.4\% completely useful. By contrast, 6.3\% indicated that they were mostly useless and another $6.3 \%$ somewhat useless.

6. How satisfied do you feel with the following aspects of the project regarding your learning progress due to creative dubbing?

6.1. The enhancement of my English speaking skills

The majority of students (75\%) indicated that the dubbing tasks had had a positive effect on their spoken English, with 31.3\% selecting somewhat useful, 31.3\% mostly useful and $12.4 \%$ completely useful. By contrast, $25 \%$ perceived the tasks to be somewhat useless. This is also important given that the goal of the project involved the improvement of speaking skills.

6.2. The improvement of my ICT skills 
The majority of students (75\%) selected positive answers, which were somewhat useful (18.75\%), mostly useful (25\%) and completely useful (31.25\%). Conversely, $6.25 \%$ selected mostly useless and $18.75 \%$ somewhat useless.

6.3. The development of my English language skills in general

The answers to this question seem to be somewhat more balanced. Once again, the positive responses were in the majority (68.8\%), with $25 \%$ choosing somewhat useful, another $25 \%$ mostly useful and $18.8 \%$ completely useful. Conversely, only $12.4 \%$ selected mostly useless and $18.8 \%$ somewhat useless.

6.4. My ability to create new dialogue exchanges for dubbing

This question evaluated the students' imaginative abilities in terms of creating dialogue exchanges, which were, consequently, related to improving their use of vocabulary and grammar. The majority of the answers were positive in this regard (81.2\%), with $18.8 \%$ choosing somewhat useful, 50\% mostly useful and $12.4 \%$ completely useful. By contrast, 6.3\% selected mostly useless and $12.5 \%$ somewhat useless.

\section{In general, did the project meet your expectations?}

7.1. With regard to the video-recorded presentation

In this case, $81.3 \%$ of the answers were positive, with $18.8 \%$ of the students choosing somewhat useful, $37.5 \%$ mostly useful and $25 \%$ completely useful. By contrast, $6.3 \%$ of the students were less positive and selected mostly useless with a further $12.4 \%$ selecting somewhat useless.

7.2. With regard to the creative dubbing task

The following data indicate that the task, which was new to the students, was viewed as an attractive opportunity to improve their spoken English. The majority of the responses were positive (93.9\%): 43.8\% of the students opted for somewhat useful, $18.8 \%$ mostly useful and $31.3 \%$ completely useful. Only $6.1 \%$ chose mostly useless.

7.3. With regard to linguistic creativity

Most of the students (75\%) selected somewhat useful, mostly useful and completely useful in equal measure, while a further $25 \%$ opted for somewhat useless.

As for the question 8 regarding participation in similar projects in the future, $87.5 \%$ of the students indicated that they would be willing to do so, provided these projects mainly involved dubbing and subtitling. This was borne out by comments such as: "I'm so happy I took part in this project", "I enjoyed it and I hope to be participating in similar projects in the future" or "It was a pleasure to have this type of activity to encourage us to enjoy the language in a different way."

Question 9, as regards the students' degree of satisfaction for having participated in the project, revealed that $25 \%$ chose somewhat useful, $43.75 \%$ mostly useful and $31.25 \%$ completely useful, which accounted for a majority of positive responses $(75 \%)$.

When asked about the tasks that they had enjoyed most (question 10), 43.75\% opted for the creative dubbing activity, $31.25 \%$ chose the video-recording task and 
$25 \%$ selected both equally. Some of their answers concerning what they had enjoyed most were: "The funny scenes in the creative dubbing videos", "Just dubbing!", and "What I enjoyed most was inventing the creative dubbing dialogues." By contrast, with regard to what they enjoyed least, some of the comments related to the technical issues they had experienced with the dubbing software program ("The main difficulty involved understanding how to handle the video editor correctly"), characterisation ("In the creative dubbing, I'd have favoured using different voices, like those of other members of my family, so my project would have been better") and language ("The times I had to repeat the same words because I was nervous").

\section{DISCUSSION}

This project has aimed to evaluate the potential of creative dubbing as a tool to improve speaking skills in business English. In this mixed methods study, quantitative and qualitative data were used to validate (or refute) the findings obtained from the analysis of all the tasks submitted by the students, along with their own perceptions once the project was completed.

The research questions, posed in subsection 3.2, will be answered in detail below.

1. Can creative dubbing be used as a valid tool for the improvement of oral production skills in English?

The results obtained by both the EG and CG were compared in order to answer this question. First, the EG practised creative dubbing tasks as a means of enhancing their business English speaking skills. This group showed an improvement of +1.02 points in this task. Although these data are not essentially relevant to this particular study, the pre-qestionnaire shows that the participants enjoyed the task, especially as it was new to all of them, and only $32 \%$ had carried out any dubbing work previously. Then, both the EG and the CG worked towards improving their spoken skills by submitting three video-recording tasks on topics related to business English. Although the average marks obtained by the CG were higher for the first submission (6.72), the group obtained 6.96 points for the second and 7.37 points for the third. This group showed an improvement of +0.65 points. The EG achieved a lower average mark for the first task with 6.12 points, but then went on to score 7.28 points for the second submission and 7.58 points for the third. This would indicate that their improvement was significantly greater when compared with that of the CG; that is to say, they improved by +1.46 points. A comparison of the improvement in both groups shows that ultimately the EG had an advantage of +0.81 points over the CG. Most importantly, 87.4\% of the students saw a significant improvement in their speaking skills (question 5.4). The students also mentioned that the creative dubbing activities had enhanced their speaking skills (question 6.1), with $75 \%$ of them giving a positive response. We can therefore conclude that the quantitative 
results obtained by the EG seem to correspond with their perceptions of what they had learnt during the course of the experiment.

Although the results obtained in the statistical tests by such a small sample cannot lead to any definitive conclusions, the statistical procedures used in the project revealed important findings. They show that there are significant differences between the mean values of the sample sets under examination. We should not attribute the improvements to pure chance; therefore, it may be assumed that the more significant development shown by the EG is somehow linked to stronger motivation and interest triggered by the extra dubbing tasks, which most of the students' seem to have enjoyed.

Despite these encouraging results, the conclusions drawn in this paper must not be taken as conclusive. The fact that the different statistical tests do not unambiguously show the influence of the creative dubbing tasks on the students' performance may well be attributed to the small size of the sample of only twenty individuals. In consequence, this article should be taken simply as an initial study whose results might motivate its replication in future larger scale research.

2. Did the students feel that they had improved any other skills through creative dubbing?

As many as $87.6 \%$ of the EG's responses to the post-questionnaire indicated that the activities proposed in the project were viewed as having had a positive effect on improving the students' linguistic creativity skills (question 5.1). Also, 68.9\% responded positively to the question of whether or not their listening comprehension skills (question 5.2) had improved, with the same percentage when it came to their writing skills (question 5.3). Other skills included the enhancement of their ICT skills (question 6.2) with 75\% of positive responses, the development of their English language skills in general (question 6.3) with $68.8 \%$ of positive answers, and the ability to create new dialogue exchanges for dubbing (question $6.4)$, with a majority of positive answers $(81.2 \%)$. However, more research should be conducted in order to explore the actual enhancement of these skills, which unfortunately cannot be considered here owing to the spatial constraints. What can be inferred, though, is that given the EG's quantitative improvement, several skills such as those mentioned here can be improved in parallel.

\section{Was the project well-received by the participants?}

The fact that the EG's results were positive and tended to be quantitatively higher than the CG's, as corroborated by their average marks, indicates that the students found the tasks interesting, which enabled them to complete the project successfully. In addition, as shown by the post-questionnaire (question 8), a majority of students $(87.5 \%)$ indicated that they would be willing to participate in similar projects in the future. Their answers regarding the aspects that they enjoyed 
most and least show that the majority were interested in the tasks, that their marks improved considerably, and that their own views on their learning outcomes were more than positive.

\section{CONCLUSION}

In this study, creative dubbing was used as a means of attaining a specific goal, namely an improvement in the speaking skills needed for the Degree in Commerce, with business English being the main area of study. This mixed methods research project meant triangulating different types of data. Accordingly, two groups were created and their results were compared. The EG, who worked on creative dubbing tasks, improved more in their video-recording tasks compared to the CG. The EG participants' responses to the questionnaire show that they felt their speaking skills had improved in addition to their writing, vocabulary (due to the creation of new exchanges), and ICT skills (required to carry out the dubbing tasks).

The statistical operations used here established a direct relationship between the use of creative dubbing as an innovative tool, on the one hand, and the proven improvement of the EG's speaking skills, on the other. However, the small number of participants could be said to limit the validity of the test results. It should also be noted that it was the participants' first experience with this type of pedagogical methodology and that the project was carried out merely as an attempt to share its results with other scholars, lecturers or teachers who might be interested in making full or partial use of it in their own classrooms.

To conclude, this study is expected to show the advantages of using AVT in business English teaching and learning. In particular, its findings would suggest that the use of tools like creative dubbing might be helpful to students who wish to enhance their oral production skills. Generally, AVT modes used in the ESP classroom appear to be a helpful and efficient tool for students, teachers and researches, who might benefit from similar projects with such promising outcomes.

[Paper submitted 14 Sep 2020]

[Revised version received 30 Dec 2020]

[Revised version accepted for publication 29 Oct 2021]

\section{References}

Ávila-Cabrera, J. J., \& Corral Esteban, A. (2021). The project SubESPSKills: Subtitling tasks for students of business English to improve written production skills. English for Specific Purposes, 63, 33-44. https://doi.org/10.1016/j.esp.2021.02.004

Baños, R. (2019). Fandubbing across time and space. In I. Ranzato, \& S. Zanotti (Eds.), Reassessing dubbing: Historical approaches and current trends (pp. 145-168). John Benjamins. https://doi.org/10.1075/btl.148.07ban 
Bogucki, Ł., \& Deckert, M. (Eds.) (2020). The Palgrave handbook of audiovisual translation and media accessibility. Palgrave Macmillan.

Bolaños-García-Escribano, A., \& Díaz-Cintas, J. (2019). Audiovisual translation: Subtitling and revoicing. In S. Laviosa, \& M. González-Davies (Eds.), The Routledge handbook of translation and education (pp. 207-225). Routledge.

Burston, J. (2005). Video dubbing projects in the foreign language curriculum. CALICO Journal, 23(1), 79-92. Retrieved from https://journals.equinoxpub.com/index.php/CALICO/article/viewFile/23166/19171

Cerezo Merchán, B., Chaume, F., Granell, X., Martí Ferriol, J. L., Martínez Sierra, J. J., Marzà, A., \& Torralba Miralles, G. (2016). La traducción para el doblaje en España [Translation for dubbing in Spain]. Publicacions de la Universitat Jaume I.

Chaume, F. (2004). Film studies and translation studies: Two disciplines at a stake in audiovisual translation. Meta, 49(1), 12-24. https://doi.org/10.7202/009016ar

Chaume, F. (2013). The turn of audiovisual translation: New audiences and new technologies. Translation Spaces, 2(1), 105-123. https://doi.org/10.1075/ts.2.06cha

Chaume, F. (2018). Is audiovisual translation putting the concept of translation up against the ropes? JoSTrans: The Journal of Specialised Translation, 30, 84-104. Retrieved from https://www.jostrans.org/issue30/art_chaume.pdf

Chaume, F. (2020). Dubbing. In Ł. Bogucki, \& M. Deckert (Eds.), The Palgrave handbook of audiovisual translation and media accessibility (pp. 103-132). Palgrave Macmillan. https://doi.org/10.1007/978-3-030-42105-2_6

Council of Europe. (2001). Common European framework of reference for languages (CEFR). Retrieved from http://www.coe.int/t/dg4/linguistic/source/Framework_EN.pdf

Danan, M. (2010). Dubbing projects for the language learner: A framework for integrating audiovisual translation into task-based instruction. Computer Assisted Language Learning, 23(5), 441-456. https://doi.org/10.1080/09588221.2010.522528

Díaz Cintas, J. (2012). Los subtítulos y la subtitulación en la clase de lengua extranjera [Subtitles and subtitling in the foreign language classroom]. Abehache, 2(3), 95-114.

Fernández-Costales, A. (2017). Subtitling in CLIL: Promoting bilingual methodologies through audiovisual translation. In C. y D. Ministerio de Educación (Ed.), Bilingual education: Trends and key concepts (pp. 185-196). Ministerio de Educación, Cultura y Deporte.

Herrero, C., \& Vanderschelden, I. (Eds.) (2019). Using film and media in the language classroom: Reflections on research-led teaching. Multilingual Matters.

Ibáñez Moreno, A., \& Vermeulen, A. (2015). Profiling a MALL app for English oral practice: A case study. Journal of Universal Computer Science, 21(10), 1339-1361. http://dx.doi.org/10.3217/jucs-021-10-1339

Incalcaterra McLoughlin, L., Lertola, J., \& Talaván, N. (Eds.) (2020). Audiovisual translation in applied linguistics: Educational perspectives (Benjamins current topics, 111). John Benjamins. https://doi.org/10.1075/bct.111

Lertola, J., \& Mariotti, C. (2017). Reverse dubbing and subtitling: Raising pragmatic awareness in Italian ESL learners. JoSTrans: The Journal of Specialised Translation, 28, 103-121. Retrieved from https://www.jostrans.org/issue28/art_lertola.pdf

Martínez Sierra, J. J. (Ed.) (2021). Multilingualism, translation and language teaching. Tirant Lo Blanch.

Robson, C., \& McCartan, K. (2016). Real world research (4th ed.). John Wiley \& Sons.

Sokoli, S., Zabalbeascoa, P., \& Fountana, M. (2011). Subtitling activities for foreign language learning: What learners and teachers think. In L. Incalcaterra McLoughlin, M. Biscio, 
\& M. Áine Ní Mhainnín (Eds.), Subtitles and subtitling: Theory and practice (pp. 219241). Peter Lang.

Talaván, N. (2013). La subtitulación en el aprendizaje de lenguas extranjeras [Subtitling in foreign language learning]. Octaedro.

Talaván, N. (2019). Creative audiovisual translation applied to foreign language education: A preliminary approach. JAT: Journal of Audiovisual Translation, 2(1), 53-74. Retrieved from https://www.jatjournal.org/index.php/jat/article/view/57/17

Talaván, N. (2020). The didactic value of AVT in foreign language education. In Ł. Bogucki, \& M. Deckert (Eds.), The Palgrave handbook of audiovisual translation and media accessibility (pp. 567-591). Palgrave Macmillan. https://doi.org/10.1007/978-3-030-42105-2_28

Talaván, N., \& Ávila-Cabrera, J. J. (2015). First insights into the combination of dubbing and subtitling as L2 didactic tools. In Y. Gambier, A. Caimi, \& C. Mariotti (Eds.), Subtitles and language learning: Principles, strategies and practical experiences (pp.149-172). Peter Lang.

Talaván, N., \& Costal, T. (2017). iDub - The potential of intralingual dubbing in foreign language learning: How to assess the task. Language Value, 9(1), 62-88. https://doi.org/10.6035/LanguageV.2017.9.4

Talaván, N., Ávila-Cabrera, J. J., \& Costal, T. (2016). Traducción y accesibilidad audiovisual [Audiovisual translation and accessibility]. Editorial UOC.

Vanderplank, R. (1998). The value of teletext sub-titles in language learning. ELT Journal, 42(4), 272-281. https://doi.org/10.1093/elt/42.4.272

Zhang, S. (2016). Mobile English learning: An empirical study on an APP, English fun dubbing. International Journal of Emerging Technologies in Learning, 11(12), 4-8. https://doi.org/10.3991/ijet.v11i12.6314

JOSÉ JAVIER ÁVILA-CABRERA works as a lecturer in the Department of English Studies at the Universidad Complutense de Madrid (Spain). He holds a PhD in English Studies from the Universidad Nacional de Educación a Distancia (UNED), specialising in the field of the subtitling of offensive and taboo terms as well as in audiovisual translation (AVT) in foreign language learning (FLL) and the use of technology in FLL.

\section{Appendix A. Video-recorded presentation 1}

Please talk for two minutes on the topic below.

Topic: You're in your forties and attend a job interview for a position in the marketing department of an international company (you can choose the company which you want to work for).

Introduce yourself, talk about your previous work experience and explain the reasons why you are the best candidate for the post.

\section{Appendix B. Video-recorded presentation 2}

Please talk for two minutes on the topic below.

Topic: You're a sales representative and you are going to use a video to advertise a product. Introduce yourself and the name of the company you belong to.

Describe the product you're selling, including: price, uses and return policy. 


\section{Appendix C. Video-recorded presentation 3}

Please talk for two minutes on the topic below.

Topic: You are a manager in a multinational and have visitors to your company who will spend a week with you.

Talk about all the activities you will be involved, including the following: eating out, visiting places of cultural importance and local markets for shopping.

\section{Appendix D. Creative dubbing task 1}

1. Watch the trailer (Tarantino's Once Upon a Time in Hollywood) and invent a creative dialogue freely in English. You should aim to talk for the time the characters take to say something or just when you hear some off-voices (voice with no person visible or narration).

2. The dialogue you create should include the following 10 terms/phrases: overtime, annual leave, get paid for, be responsible for, deliver happiness, complaints, customer satisfaction, give a presentation, rearrange a meeting, and move it back (to).

\section{Appendix E. Creative dubbing task 2}

1. Watch the trailer (Scorsese's The Wolf of Wall Street) and invent a creative dialogue freely in English. You should aim to talk for the time the characters take to say something or just when you hear some off-voices (voice with no person visible or narration).

2. The dialogue you create should include the following 10 terms/phrases: freshen up, pick (someone) up, drop (someone) off, auditorium, inventory, keep track of, run low on, think and plan, hierarchical structure, and come up with an idea.

\section{Appendix F. Post-questionnaire}

Surname(s) and name(s)

\section{Creative Dubbing post-questionnaire - 2019-2020}

Mother tongue: Spanish

Gender: Male

Chinese

Arabic

Age:

18-20

Female

Over 20

1. Have you completed all the tasks ( 3 video-recordings +2 creative dubbing tasks)?

$$
\text { Yes, all of them No, just some Other }
$$

2. How long did it take you to complete each of the video-recording tasks?
1-3 hours
3-5 hours
Over 5 hours

3. How long did it take you to complete each of the creative dubbing tasks?
1-3 hours
3-5 hours
Over 5 hours

4. Did you find any technical challenges with the video-recordings/dubbing of the videos?

\section{[Questions 5, 6 and 7 in section 4.3.]}

8. Would you like to participate in similar projects in the future?

$$
\text { Absolutely yes I am not sure I don't think so Other }
$$

9. Mark your degree of satisfaction with regard to your participation in the project.

1 I did not find the project rewarding enough [...] 6 I found the project extremely rewarding

10. Please include here what you enjoyed most and least in this project. 